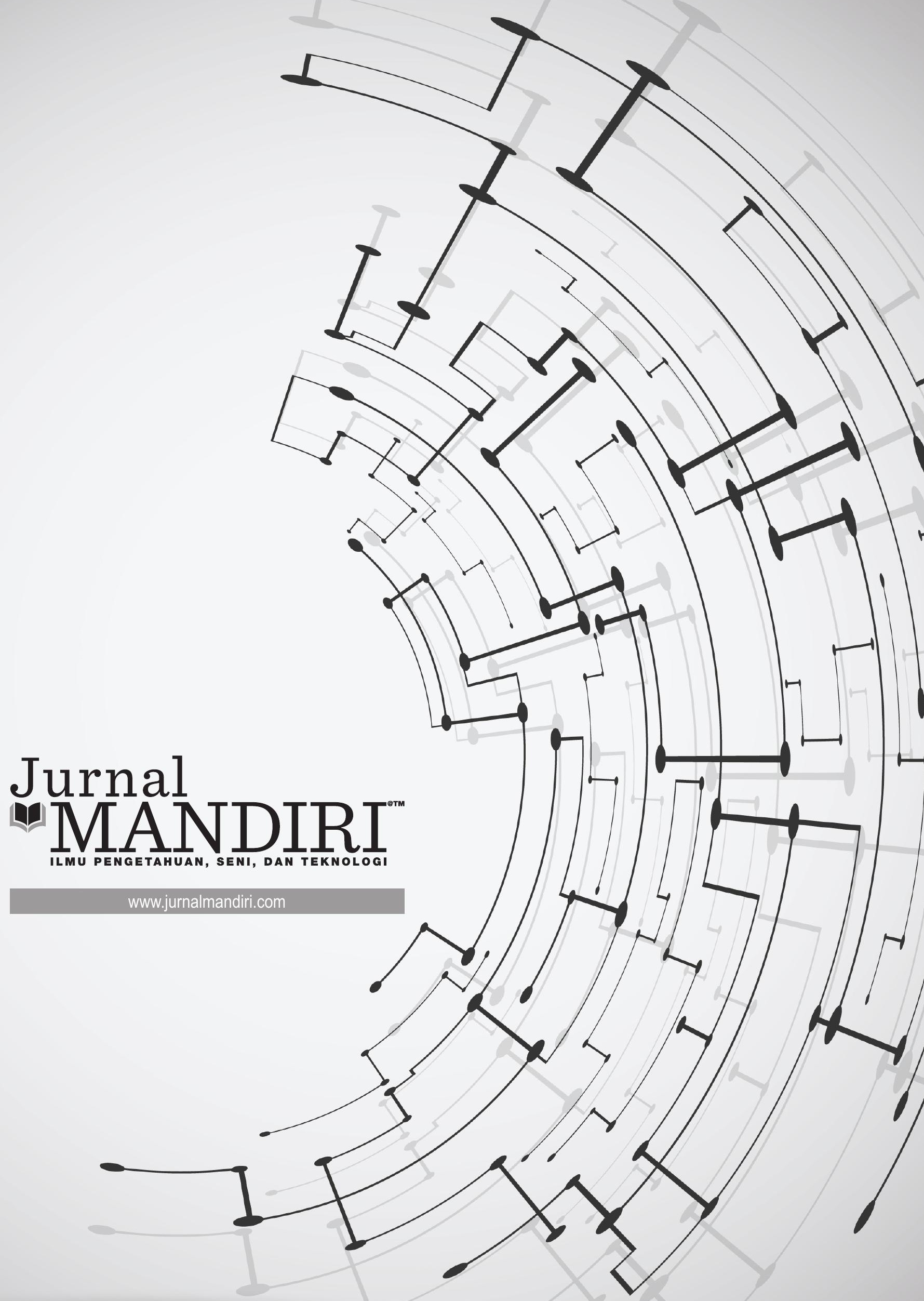


ISSN : 2580-3220, E-ISSN : 2580-4588

J. Mandiri., Vol. 3, No. 2, Desember 2019 (194 - 206)

C2018 Lembaga Kajian Demokrasi

dan Pemberdayaan Masyarakat (LKD-PM)

DOI : https://doi.org/10.33753/mandiri.v3i2.79

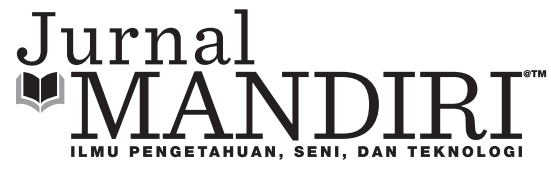

\title{
Pengaruh Kepemimpinan dan Motivasi Terhadap Kinerja Pegawai (Studi Pada Direktorat Pengembangan Ekonomi Lokal Kementerian Desa, Pembangunan Daerah Tertinggal, dan Transmigrasi)
}

\author{
Syamsi Mawardi \\ Fakultas Ekonomi, Universitas Pamulang \\ awansm86@gmail.com
}

\begin{abstract}
Abstrak
Perumusan masalah dalam penelitian yaitu seberapa besar pengaruh kepemimpinan dan motivasi secara bersama-sama terhadap kinerja pegawai pada Direktorat Pengembangan Ekonomi Lokal Kementerian Desa, Pembangunan Daerah Tertinggal dan Transmigrasi. Metode penelitian menggunakan survei dengan pendekatan kuantitatif yang bersifat korelasional. Teknik penarikan sampel yang digunakan berdasarkan tabel yang dikembangkan oleh Isaac dan Michael. Dalam penelitian ini jumlah sampel sebanyak 32 responden. Berdasarkan hasil penelitian yang telah dilakukan, maka dapat disimpulkan bahwa uji hipotesis korelasi ganda variabel kepemimpinan dan motivasi secara bersama-sama terhadap kinerja pegawai pada Direktorat Pengembangan Ekonomi Lokal Kementerian Desa Pembangunan Daerah Tertinggal dan Transmigrasi, ternyata memiliki pengaruh yang positif kuat dan signifikan dengan nilai koefisien korelasi sebesar 0,738 dengan uji Fhitung sebesar 17,376 > dari Ftabel sebesar 3,33. Sedang koefisien determinasinya r2 =0,545, hal ini berarti secara bersama-sama kinerja pegawai sebesar 54,5\% ditentukan oleh kepemimpinan dan motivasi, sisanya $45,5 \%$ ditentukan oleh faktor lain.
\end{abstract}

Kata Kunci : Kepemimpinan, Motivasi, Kinerja Pegawai

\begin{abstract}
Formulation of the problem in the research is how much influence leadership and motivation jointly have on employee performance at the Directorate of Local Economic Development Ministry of Village, Development of Disadvantaged Regions and Transmigration. The research method uses surveys with a correlational quantitative approach. The sampling technique used is based on a table developed by Isaac and Michael. In this study the number of samples was 32 respondents. Based on the results of the research that has been done, it can be concluded that the hypothesis test of the multiple correlation of leadership variables and motivation together on the performance of employees in the Directorate of Local Economic Development Ministry of Village Development of Disadvantaged Regions and Transmigration, turns out to have a strong and significant positive effect with coefficient values correlation of 0.738 with a calculated $F$ test of $17.376>$ of Ftable of 3.33 . While the determination coefficient $r 2=0.545$, this means that together the employee performance of $54.5 \%$ is determined by leadership and motivation, the remaining $45.5 \%$ is determined by other factors.
\end{abstract}

Keywords : Leadership, Motivation, Employee Performance

\section{PENDAHULUAN}

Sejalan dengan perkembangan dunia yang semakin global, pengelolaan Direktorat Pengembangan Ekonomi Lokal Kementerian Desa, 
Pembangunan Daerah Tertinggal dan Transmigrasi harus dilakukan secara professional serta produktif, sehingga instansi tersebut tetap dapat terus berkembang seiring dengan kemajuan jaman. Konsep pengembangan umumnya dilakukan terhadap pegawai yang berfungsi sebagai roda penggerak organisasi. Pengembangan pegawai harus dilakukan dengan kontinuitas yang terpelihara baik serta terarah. Satu hal yang perlu diperhatikan adalah pegawai sebagai sumber daya manusia yang handal tidak muncul begitu saja, namun memerlukan suatu proses pengembangan yang bertahap dan berkesinambungan.

Untuk mencapai kinerja atau prestasi kerja pegawai yang maksimal, penggunaan kepemimpinan yang tepat dari atasan, merupakan salah satu faktor yang dapat menggerakkan, mengarahkan, membimbing dan memotivasi pegawai untuk lebih berprestasi dalam bekerja. Pemimpin dapat mempengaruhi moral, kepuasan kerja, keamanan, kualitas kehidupan kerja dan terutama tingkat prestasi suatu organisasi. Kemampuan dan keterampilan kepemimpinan dalam pengarahan adalah faktor penting efektivitas pemimpin. Bila organisasi dapat mengidentifikasikan kualitaskualitas yang berhubungan dengan kepemimpinan, kemampuan untuk menyeleksi pemimpinpemimpin yang efektif akan meningkat, bila organisasi dapat mengidentifikasikan perilaku dan teknik-teknik kepemimpinan efektif organisasi, berbagai perilaku dan teknik tersebut akan dapat dipelajari.

Penilaian kinerja pegawai adalah proses melalui hal mana organisasi mengevaluasi atau menilai prestasi kerja pegawai. Kegiatan ini dapat memperbaiki keputusan-keputusan personalia dan memberikan umpan balik kepada para pegawai tentang pelaksanaan kerja mereka.

Kegunaan-kegunaan penilaian kinerja dapat dirinci sebagai berikut, perbaikan prestasi kerja, penyesuaian-penyesuaian kompensasi, keputusan-keputusan penempatan, kebutuhan latihan dan pengembangan, perencanaan dan pengembangan karier, penyimpangan-penyimpangan proses staffing, ketidakakuratan informasional, kesalahan desain pekerjaan, kesempatan kerja yang adil dan tantangan-tantangan eksternal.

Disamping faktor kepemimpinan, faktor motivasi juga dapat mempengaruhi kinerja pegawai yang dimiliki seseorang adalah merupakan potensi, dimana seseorang belum tentu bersedia untuk mengerahkan segenap potensi yang dimilikinya untuk mencapai hasil yang optimal, sehingga masih diperlukan adanya pendorong agar seorang pegawai pada Direktorat Pengembangan Ekonomi Lokal Kementerian Desa, Pembangunan Daerah Tertinggal dan Transmigrasi mau menggunakan seluruh potensinya. Daya dorong tersebut sering disebut motivasi. Melihat kenyataan tersebut, sudah saatnya pimpinan dapat lebih banyak memberikan kesempatan kepada pegawai mengembangkan sumber daya manusia agar lebih berprestasi dalam melaksanakan tugas pelayanan terhadap masyarakat.

Dengan demikian kiranya perlu dirumuskan secara mendalam, usaha-usaha secara terpadu dan berkesinambungan melalui penerapan analisis kepemimpinan dan motivasi terhadap kinerja pegawai yang dikembangkan di lingkungan Direktorat Pengembangan Ekonomi Lokal Kementerian Desa, Pembangunan Daerah Tertinggal dan Transmigrasi.

Namun dalam kenyataannya masih terdapat beberapa hal yang menghambat dalam pencapaian kinerja pegawai secara maksimal di lingkungan Direktorat Pengembangan Ekonomi Lokal Kementerian Desa, Pembangunan Daerah Tertinggal dan Transmigrasi, yang diduga disebabkan oleh beberapa faktor, seperti: kepemimpinan yang belum mampu merangkul seluruh bawahan, kurangnya kemampuan pimpinan dalam mengemban tugas dan tanggungjawabnya secara maksimal, motivasi kerja pegawai yang kurang maksimal, penghargaan terhadap prestasi kerja pegawai masih rendah, disiplin kerja pegawai belum maksimal dan fasilitas kerja masih belum mendukung kegiatan kerja pegawai.

Berdasarkan landasan teori di atas, maka dapat dirumuskan hipotesis sebagai berikut:

$\mathrm{H}_{\mathrm{ol}}$ : Tidak terdapat pengaruh kepemimpinan terhadap kinerja pegawai pada Direktorat Pengembangan Ekonomi Lokal Kemen- 
terian Desa, Pembangunan Daerah Tertinggal dan Transmigrasi.

$\mathrm{H}_{\mathrm{a} 1}$ : Terdapat pengaruh kepemimpinan terhadap kinerja pegawai pada Direktorat Pengembangan Ekonomi Lokal Kementerian Desa, Pembangunan Daerah Tertinggal dan Transmigrasi.

$\mathrm{H}_{\mathrm{o} 2}$ : Tidak terdapat pengaruh motivasi terhadap kinerja pegawai pada Direktorat Pengembangan Ekonomi Lokal Kementerian Desa, Pembangunan Daerah Tertinggal dan Transmigrasi.

$\mathrm{H}_{\mathrm{a} 2}$ : Terdapat pengaruh motivasi terhadap kinerja pegawai pada Direktorat Pengembangan Ekonomi Lokal Kementerian Desa, Pembangunan Daerah Tertinggal dan Transmigrasi.

$\mathrm{H}_{03}$ : Tidak terdapat pengaruh kepemimpinan dan motivasi secara bersama-sama terhadap kinerja pegawai pada Direktorat Pengembangan Ekonomi Lokal Kementerian Desa, Pembangunan Daerah Tertinggal dan Transmigrasi.

$\mathrm{H}_{\mathrm{a3}}$ : Terdapat pengaruh kepemimpinan dan motivasi secara bersama-sama terhadap kinerja pegawai pada Direktorat Pengembangan Ekonomi Lokal Kementerian Desa, Pembangunan Daerah Tertinggal dan Transmigrasi.

Dengan keterbatasan penelitian serta agar lebih mudah dipahami dan dimengerti maka penelitian ini penulis memberikan Batasan-batasan yang diteliti, yaitu mengenai kepemimpinan dan motivasi pengaruhnya terhadap kinerja pegawai pada Direktorat Pengembangan Ekonomi Lokal, Kementerian Desa, Pembangunan Daerah Tertinggal dan Transmigrasi dengan cara menyebarkan kuisioner kepada pegawai.

\section{METODE}

Penelitian ini menggunakan metode penelitian survei dengan pendekatan kuantitatif, yang bersifat korelasional di mana untuk melihat seberapa besar pengaruh variabel bebas terhadap variabel terikat, yaitu variabel kepemimpinan dan motivasi terhadap kinerja pegawai. Penelitian dilakukan pada sekelompok individu yakni pegawai Direktorat Pengembangan Ekonomi Lokal, Direktorat Jenderal Pembangunan Daerah Tertinggal, Kementerian Desa, Pembangunan Daerah Tertinggal dan Transmigrasi yang beralamat di Jalan Abdul Muis No 07 - Jakarta Pusat.

Populasi dalam penelitian ini adalah para pegawai pada Direktorat Pengembangan Ekonomi Lokal Kementerian Desa, Pembangunan Daerah Tertinggal dan Transmigrasi yang memiliki jumlah pegawai sebanyak 35 orang.

Pada penelitian ini teknik penarikan sampel yang digunakan berdasarkan tabel penentuan sampel yang dikembangkan oleh Isaac dan Michael (Sugiyono, 2014:99), yang dapat dijelaskan pada tabel di bawah ini.

\begin{tabular}{|c|c|c|c|}
\hline \multirow{2}{*}{ N } & \multicolumn{3}{|c|}{ S } \\
\hline & $1 \%$ & $5 \%$ & $10 \%$ \\
\hline 10 & 10 & 10 & 10 \\
\hline 15 & 15 & 14 & 14 \\
\hline 20 & 19 & 19 & 19 \\
\hline 25 & 24 & 23 & 23 \\
\hline 30 & 29 & 28 & 27 \\
\hline 35 & 33 & 32 & 31 \\
\hline 40 & 38 & 36 & 35 \\
\hline 45 & 42 & 40 & 39 \\
\hline 50 & 47 & 44 & 42 \\
\hline 55 & 51 & 48 & 46 \\
\hline 60 & 55 & 51 & 49 \\
\hline 65 & 59 & 55 & 53 \\
\hline 70 & 63 & 58 & 56 \\
\hline 75 & 67 & 62 & 59 \\
\hline 80 & 71 & 65 & 62 \\
\hline 85 & 75 & 68 & 65 \\
\hline 90 & 79 & 72 & 68 \\
\hline 95 & 83 & 75 & 71 \\
\hline 100 & 87 & 78 & 73 \\
\hline
\end{tabular}

Berdasarkan tabel dari Isaac dan Michael tersebut maka dapat ditentukan jumlah sampel pada Direktorat Pengembangan Ekonomi Lokal Kementerian Desa, Pembangunan Daerah Tertinggal dan Transmigrasi, dengan jumlah populasi sebanyak 35 orang pegawai dan taraf kesalahan $5 \%$ maka didapat jumlah sampel sebesar 32 orang responden. 


\section{HASIL dan PEMBAHASAN}

Dalam landasan teori ini akan dibahas pengertian dari teori yang berkaitan dengan permasalahan yang dikaji dalam tesis ini, yaitu kepemimpinan sebagai variabel independen (variabel bebas $\mathrm{X}_{1}$ ), motivasi sebagai variabel independen (variabel bebas $\mathrm{X}_{2}$ ), dan kinerja pegawai sebagai variabel dependen (variabel terikat Y), yang dapat diuraikan sebagai berikut:

Konsep pemimpin berasal dari kata asing "leader" dan kepemimpinan dari "leadership". Pemimpin merupakan salah satu intisari manajemen, sumber daya pokok dan titik sentral dari setiap aktivitas yang terjadi dalam suatu organisasi. Bagaimana kreativitas dan dinamikanya seseorang pemimpin dalam menjalankan wewenang kepemimpinannya akan sangat menentukan apakah tujuan organisasi dapat dicapai atau tidak. Pemimpin yang dinamis dan kreatif maka organisasi yang dipimpinnya juga akan semakin dinamis dan aktivitas-aktivitas yang akan dilakukan akan semakin banyak, demikian Malayu S.P. Hasibuan (2014:43), menyatakan pemimpin seseorang dengan wewenang kepemimpinannya mengarahkan bawahannya untuk mengerjakan sebagian dari pekerjaannya dalam mencapai tujuan. Menurut Haryono Sudriamunawar (2006:1), mengemukakan bahwa: "Pemimpin adalah seseorang yang memiliki kecakapan tertentu yang dapat mempengaruhi para pengikutnya untuk melakukan kerja sama ke arah pencapaian tujuan yang telah ditentukan sebelumnya”.

Berdasarkan definisi di atas maka dapat disimpulkan bahwa kepemimpinan adalah kemampuan pemimpin dalam mempengaruhi orang lain dalam melakukan kerja sama untuk mencapai tujuan yang telah ditentukan. Jadi kepemimpinan merupakan aspek yang paling nyata dari kegiatan manajemen, yang berindikasikan fokus untuk proses, mempengaruhi orang lain, tingkah laku dan mencapai tujuan.

Motif atau motivasi berasal dari kata latin "moreve" yang berarti dorongan dari dalam diri manusia untuk bertindak atau berperilaku. Pengertian motivasi tidak terlepas dari kata kebutuhan atau "needs" atau "want". Kebutuhan adalah suatu potensi dalam diri manusia yang perlu ditanggapi atau direspons.

Pengertian motivasi bervariasi, hal ini disebabkan karena beberapa ahli mendefinisikannya sesuai dengan pandangannya masing-masing. Manulang (2001:107), menjelaskan bahwa motivasi adalah daya perangsang atau daya pendorong, yang merangsang/mendorong pegawai untuk mau bekerja dengan segiat-giatnya berbeda antara pegawai yang satu dengan pegawai lainnya. Sedangkan Ishak Arep dan Hendri Tanjung (2003:12), mengemukakan motivasi adalah sesuatu yang pokok, yang menjadi dorongan seseorang untuk bekerja.

Maslow (2000:13), seorang ahli psikologi telah mengembangkan teori motivasi mendasarkan pada kebutuhan manusia yang dibedakan antara kebutuhan biologis dan kebutuhan psikologis, atau disebut kebutuhan materil (biologis) dan kebutuhan non material (psikologis).

Dari pengertian tersebut di atas, dapat disimpulkan bahwa motivasi pada dasarnya merupakan interaksi seseorang dengan situasi tertentu yang dihadapinya orang tersebut dan di dalam dirinya terdapat "kebutuhan" atau "keinginan" terhadap obyek di luar diri orang tersebut, kemudian bagaimana dia menghubungkan antara kebutuhan dengan "situasi di luar" obyek tersebut dalam rangka memenuhi kebutuhan yang dimaksud melalui berbuat berarti, imbalan, bersikap adil, umpan balik dan bergaul dengan rekan kerja.

Performance sering diartikan sebagai kinerja, hasil kerja atau prestasi kerja. Kinerja mempunyai makna lebih luas, bukan hanya menyatakan sebagai hasil kerja, tetapi termasuk bagaimana proses pekerjaan berlangsung. Kinerja adalah tentang melakukan pekerjaan dan hasil yang dicapai dari pekerjaan tersebut. Kinerja adalah tentang apa yang dikerjakan dan bagaimana cara mengerjakanya kinerja merupakan hasil pekerjaan yang mempunyai hubungan kuat dengan tujuan strategis organisasi.

Istilah kinerja yang berasal dari job performance (kinerja yang dicapai seseorang). Pengertian kinerja adalah hasil kerja secara kualitas dan kuantitas yang dicapai oleh seorang pegawai dalam melaksanakan tugasnya sesuai dengan tanggung jawab yang diberikan kepadanya. 
Dalam buku Himpunan Peraturan Perundang-undang Pegawai Negeri Sipil (2004:3), menyatakan bahwa Pegawai Negeri adalah setiap warga negara Republik Indonesia yang telah memenuhi syarat yang ditentukan, diangkat oleh pejabat yang berwenang dan diserahi tugas dalam suatu jabatan negeri, atau diserahi tugas negara lainnya, dan digaji berdasarkan peraturan perundang-undangan yang berlaku".

Robbins dalam Moeheriono (2009:61), bahwa kinerja sebagai fungsi interaksi antara kemampuan atau ability (A), motivasi atau motivation $(\mathrm{M})$ dan kesempatan atau opportunity $(\mathrm{O})$, yaitu kinerja $=\mathrm{f}(\mathrm{AxMxO})$ artinya kinerja merupakan fungsi dari kemampuan, motivasi dan kesempatan.

Suyadi Prawirosentono (2000:2), mengatakan bahwa performance atau kinerja adalah hasil kerja yang dapat dicapai oleh seseorang atau sekelompok orang dalam suatu organisasi, sesuai dengan wewenang dan tanggung jawab masing-masing, dalam rangka upaya mencapai tujuan organisasi bersangkutan secara legal, tidak melanggar hukum dan sesuai dengan moral maupun etika”.

Prasetya Irawan (2000:1), menyatakan bahwa kinerja adalah "merupakan hasil dari suatu proses manajemen secara menyeluruh yang melibatkan faktor-faktor efisiensi, efektivitas, dan produktivitas, di mana hasil kerja tersebut dapat ditunjukkan secara konkret, dan dapat diukur".

Menurut A.A. Anwar Prabu Mangkunegara (2004:67), "Kinerja adalah hasil kerja secara kualitas dan kuantitas yang dicapai oleh seseorang pegawai dalam melaksanakan tugasnya sesuai dengan tanggung jawab yang diberikan kepadanya".

Dari beberapa pendapat pakar manajemen di atas, maka dapat dipahami bahwa pengertian kinerja adalah suatu prestasi atau hasil kerja yang dicapai oleh individu, kelompok, dan organisasi bisa berupa barang, jasa ataupun suatu proses. Pencapaian hasil kerja itu mencerminkan terwujudnya pelaksanaan kegiatan, program dan kebijakan sebagai wujud dari tujuan organisasi secara menyeluruh.

Dari hasil definisi di atas dapat disimpulkan kinerja pegawai adalah hasil kerja yang dapat dicapai oleh seseorang atau sekelompok orang dalam suatu organisasi melalui kualitas kerja yang dihasilkan, kuantitas, baik secara kuantitatif maupun kualitatif, sesuai dengan kewenangan dan tugas tanggung jawab masing-masing, sikap pegawai dan konsistensi pegawai serta tidak melanggar hukum dan sesuai dengan moral dan etika dikarenakan adanya motivasi yang tinggi.

\section{Hasil}

Untuk menganalisis korelasi antara 2 variabel yaitu variabel independen kepemimpinan $\left(\mathrm{X}_{1}\right)$ terhadap variabel dependen kinerja pegawai $(\mathrm{Y})$ atau variabel independen motivasi $\left(\mathrm{X}_{2}\right)$ terhadap variabel dependen kinerja pegawai $(\mathrm{Y})$ dan variabel independen kepemimpinan $\left(\mathrm{X}_{1}\right)$ terhadap variabel independen motivasi $\left(\mathrm{X}_{2}\right)$ digunakan teknik analisis korelasi dengan menghitung koefisien korelasinya $\left(\mathrm{r}_{\text {hitung }}\right)$ berdasarkan rumus korelasi sederhana Pearson Product Moment. Sedangkan untuk melakukan korelasi terhadap korelasi antara variabel independen kepemimpinan $\left(\mathrm{X}_{1}\right)$ dan motivasi $\left(\mathrm{X}_{2}\right)$ secara bersama-sama terhadap variabel dependen kinerja pegawai $(\mathrm{Y})$, penulis melakukan perhitungan koefisien korelasinya berdasarkan rumus korelasi ganda. Selanjutnya nilai koefisien korelasi diperoleh, penulis konsultasikan dengan tabel interprestasi sebagai pedoman untuk menginterprestasikan kategori koefisien korelasi.

Dalam melakukan pengujian terhadap signifikansi pengaruh yang ditemukan antara variabel kepemimpinan $\left(\mathrm{X}_{1}\right)$ terhadap kinerja pegawai $(\mathrm{Y})$ dan antara motivasi $\left(\mathrm{X}_{2}\right)$ terhadap kinerja pegawai (Y) yang kemungkinannya untuk diberlakukan pada seluruh populasi, penulis menggunakan pengujian dengan menggunakan rumus Uji Signifikansi Korelasi Pearson Product Moment. Selanjutnya berdasarkan rumus uji signifikansi ini diperoleh nilai $\mathrm{t}_{\text {hitung }}$ untuk dikonsultasikan kepada harga $t_{\text {tabel }}$ pada taraf kesalahan $5 \%$, uji dua pihak dan $\mathrm{dk}=\mathrm{n}-\mathrm{k}$ dengan ketentuan jika $\mathrm{t}_{\text {hitung }}>\mathrm{t}_{\text {tabel }}$ maka $\mathrm{H}_{\mathrm{o}}$ ditolak dan $\mathrm{H}_{\mathrm{a}}$ diterima, dan jika $\mathrm{t}_{\text {hitung }}<\mathrm{t}_{\text {tabel }}$ maka $\mathrm{H}_{\mathrm{o}}$ diterima dan $\mathrm{H}_{\mathrm{a}}$ ditolak. Sedangkan untuk menguji signifikansi pengaruh korelasi berganda, penulis menggunakan pengujian perhitungan uji signifikansi korelasi berganda berdasarkan rumus $\mathrm{F}_{\text {hitung. }}$. Hasil $\mathrm{F}_{\text {hitung }}$ kemudian 
dikonsultasikan dengan $\mathrm{F}_{\text {tabel }}$ berdasarkan $\mathrm{dk}$ pembilang $=\mathrm{k}$, dk penyebut $=(\mathrm{n}-\mathrm{k}-1)$ pada taraf kesalahan 5\% dengan ketentuan jika $\mathrm{F}_{\text {hitung }}>\mathrm{F}_{\text {tabel }}$ maka koefisien korelasi berganda yang diuji termasuk dalam kategori signifikan, yang berarti dapat berlaku untuk seluruh populasi.

Untuk memprediksi besarnya pengaruh variabel independen terhadap variabel dependen, penulis menggunakan rumus determinasi yakni dengan cara mengkuadratkan nilai koefisien korelasi yang diperoleh $(\mathrm{R})^{2}$.

Untuk melihat dan mengetahui pengaruh antara variabel kepemimpinan dan motivasi terhadap variabel kinerja pegawai maka digunakan perhitungan analisis sebagai berikut:

Uji Hipotesis Pengaruh Kepemimpinan $\left(\mathrm{X}_{1}\right)$ terhadap Kinerja Pegawai (Y)

Hipotesis nol $\left(\mathrm{H}_{\mathrm{o}}\right)$ : Tidak terdapat pengaruh yang positif dan signifikan variabel kepemimpinan $\left(\mathrm{X}_{1}\right)$ terhadap kinerja pegawai $(\mathrm{Y})$.

Hipotesis alternatif $\left(\mathrm{H}_{\mathrm{a}}\right)$ : Terdapat pengaruh yang positif dan signifikan variabel kepemimpinan $\left(\mathrm{X}_{1}\right)$ terhadap kinerja pegawai $(\mathrm{Y})$.

Untuk menguji hipotesis tersebut penulis menggunakan analisa Product Moment. Adapun rumus analisa korelasi Product Moment adalah:

$$
r x_{1} y=\frac{\sum x_{1} y}{\sqrt{\left(\sum x_{1}^{2}\right)\left(\sum y^{2}\right)}}
$$

Selanjutnya untuk menghitung nilai, $\mathrm{rx}_{1} \mathrm{y}$ yaitu antara kepemimpinan terhadap kinerja pegawai pada Direktorat Pengembangan Ekonomi Lokal Kementerian Desa Pembangunan Daerah Tertinggal dan Transmigrasi, penulis menggunakan tabel penolong (Lampiran 11), hasil perhitungannya adalah sebagai berikut:

$$
\begin{aligned}
& r x_{1} y=\frac{\sum x_{1} y}{\sqrt{\left(\sum x_{1}^{2}\right)\left(\sum y^{2}\right)}} \\
& r_{x_{1} y}=\frac{4,229}{\sqrt{(6,516)(5,255)}} \\
& r_{x_{1} y}=\frac{4,229}{\sqrt{34,242}}
\end{aligned}
$$

$$
\begin{aligned}
& r_{x_{1} y}=\frac{4,229}{5,852} \\
& r_{x_{1} y}=0,723
\end{aligned}
$$

Berdasarkan hasil perhitungan tersebut, maka koefisien korelasinya yang ditemukan adalah $\operatorname{rx}_{1} y=0,723$. Setelah nilai ini dikonsultasikan dengan tabel pedoman interpretasi sebelumnya, maka diketahui bahwa koefisien korelasi tersebut termasuk ke dalam kategori yang positif kuat karena berada diantara interval $(0,600-0,799)$. Hal ini menunjukkan bahwa kepemimpinan mempunyai pengaruh yang positif dan kuat terhadap kinerja pegawai pada Direktorat Pengembangan Ekonomi Lokal Kementerian Desa Pembangunan Daerah Tertinggal dan Transmigrasi.

Sedangkan untuk mengetahui kontribusi kepemimpinan terhadap kinerja pegawai dapat dihitung dengan koefisien determinasinya $(r)^{2}$ dengan menggunakan rumus sebagai berikut:

$$
\begin{aligned}
\mathrm{Kd} & =\mathrm{r}^{2} \times 100 \% \\
& =(0,723)^{2} \times 100 \% \\
& =0,522 \times 100 \% \\
& =52,2 \%
\end{aligned}
$$

Berdasarkan perhitungan tersebut, maka hal ini berarti kepemimpinan sebesar 52,2\% mempengaruhi kinerja pegawai sedangkan sisanya sebesar 47,8\% dipengaruhi oleh faktor lain.

Selanjutnya untuk mengetahui apakah pengaruh kepemimpinan terhadap kinerja pegawai pada Direktorat Pengembangan Ekonomi Lokal Kementerian Desa Pembangunan Daerah Tertinggal dan Transmigrasi signifikan atau tidak, maka perlu diuji signifikannya dengan menggunakan rumus $t$, yaitu sebagai berikut:

$$
\begin{aligned}
& t=\frac{r \sqrt{n-2}}{\sqrt{1-r^{2}}} \\
& t=\frac{0,723 \sqrt{32-2}}{\sqrt{1-(0,723)^{2}}} \\
& t=\frac{3,958}{0,691} \\
& t=5,727
\end{aligned}
$$


Dari hasil perhitungan tersebut di atas maka diperoleh nilai thitung sebesar $=5,727$ selanjutnya nilai tersebut dibandingkan dengan nilai ttabel untuk kesalahan 5\%, dengan menggunakan uji dua pihak di mana $\mathrm{dk}=\mathrm{n}-\mathrm{k} ; 32-2=30$, dan diperoleh nilai $\mathrm{t}_{\text {tabel }}$ sebesar $=2,042$.

Berdasarkan hasil perhitungan tersebut, maka dapat dinyatakan bahwa $\mathrm{t}_{\text {hitung }}$ jatuh pada daerah penolakan $\mathrm{H}_{\mathrm{o}}$, sehingga dapat ditarik kesimpulan bahwa hipotesis nol $\left(\mathrm{H}_{\mathrm{o}}\right)$ yang menyatakan tidak terdapat pengaruh yang positif dan signifikan antara kepemimpinan terhadap kinerja pegawai "ditolak" dan hipotesis alternatif $\left(\mathrm{H}_{\mathrm{a}}\right)$ yang menyatakan terdapat pengaruh yang positif dan signifikan antara kepemimpinan terhadap kinerja pegawai "diterima". Jadi kesimpulannya $\mathrm{t}_{\text {hitung }}$ jatuh pada daerah $\mathrm{H}_{a}$ yaitu hipotesis diterima dimana koefisien korelasi antara kepemimpinan terhadap kinerja pegawai sebesar 0,723 adalah positif kuat dan signifikan, artinya koefisien tersebut dapat diberlakukan untuk seluruh populasi.

Uji Hipotesis Pengaruh Motivasi $\left(\mathrm{X}_{2}\right)$ terhadap Kinerja Pegawai (Y)

Hipotesis yang penulis ajukan untuk dianalisis adalah sebagai berikut:

a) Hipotesis nol $\left(\mathrm{H}_{\mathrm{o}}\right)$ : Tidak terdapat pengaruh yang positif dan signifikan variabel motivasi $\left(\mathrm{X}_{2}\right)$ terhadap kinerja pegawai $(\mathrm{Y})$.

b) Hipotesis alternatif $\left(\mathrm{H}_{\mathrm{a}}\right)$ : Terdapat pengaruh yang positif dan signifikan variabel motivasi $\left(\mathrm{X}_{2}\right)$ terhadap kinerja pegawai $(\mathrm{Y})$.

Untuk menguji hipotesis antara motivasi terhadap kinerja pegawai penulis menggunakan analisa Product Moment. Adapun rumus analisa korelasi Product Moment (Sugiyono, 2009) adalah sebagai berikut:

$$
r_{x_{2} y}=\frac{\sum x_{2} y}{\sqrt{\left(\sum x_{2}{ }^{2}\right)\left(\sum y^{2}\right)}}
$$

Untuk menghitung harga $\mathrm{rx}^{2} \mathrm{y}$, yaitu motivasi terhadap kinerja pegawai di Direktorat Pengembangan Ekonomi Lokal Kementerian Desa Pembangunan Daerah Tertinggal dan Transmigrasi, hasil perhitungannya adalah sebagai berikut:

$$
\begin{aligned}
& r_{x_{2} y}=\frac{\sum x_{2} y}{\sqrt{\left(\sum x_{2}^{2}\right)\left(\sum y^{2}\right)}} \\
& r_{x_{2} y}=\frac{3,576}{\sqrt{(5,182)(5,255)}} \\
& r_{x_{2} y}=\frac{3,576}{\sqrt{27,232}} \\
& r_{x_{2} y}=\frac{3,576}{5,218} \\
& r_{x_{2} y}=0,685
\end{aligned}
$$

Berdasarkan hasil perhitungan tersebut, maka koefisien korelasinya yang ditemukan adalah $\mathrm{rx}^{2} \mathrm{y}$ $=0,685$. Setelah nilai ini dikonsultasikan dengan tabel pedoman interpretasi sebelumnya, maka dapat diketahui bahwa koefisien korelasi tersebut termasuk ke dalam kategori yang positif kuat. Hal ini menunjukkan bahwa motivasi mempunyai pengaruh positif kuat terhadap kinerja pegawai. Sedangkan untuk mengetahui kontribusi motivasi terhadap kinerja pegawai dapat dihitung dengan koefisien determinasinya $(r)^{2}$ dengan menggunakan rumus sebagai berikut:

$$
\begin{aligned}
\mathrm{Kd} & =\mathrm{r}^{2} \times 100 \% \\
& =(0,685)^{2} \times 100 \% \\
& =0,470 \times 100 \% \\
& =47,0 \%
\end{aligned}
$$

Berdasarkan perhitungan tersebut, maka hal ini berarti motivasi sebesar 47,0\% mempengaruhi kinerja pegawai sedangkan sisanya sebesar 53,0\% dipengaruhi oleh faktor lain.

Selanjutnya untuk mengetahui apakah pengaruh antara motivasi terhadap kinerja pegawai pada Direktorat Pengembangan Ekonomi Lokal Kementerian Desa Pembangunan Daerah Tertinggal dan Transmigrasi signifikan atau tidak, maka perlu diuji signifikansinya dengan menggunakan rumus $t$, yaitu sebagai berikut:

$$
\begin{aligned}
& \mathrm{t}=\frac{\mathrm{r} \sqrt{\mathrm{n}-2}}{\sqrt{1-\mathrm{r}^{2}}} \\
& \mathrm{t}=\frac{0,685 \sqrt{32-2}}{\sqrt{1-(0,685)^{2}}}
\end{aligned}
$$




$$
\mathrm{t}=\frac{3,753}{0,728}
$$

$$
\mathrm{t}=5,153
$$

Dari hasil perhitungan diperoleh nilai thitung $=5,153$, selanjutnya dibandingkan dengan nilai $\mathrm{t}_{\text {tabel }}$ untuk kesalahan 5\% uji dua pihak dan $\mathrm{dk}=$ $\mathrm{n}-\mathrm{k} ; 32-2=30$, dan diperoleh $\mathrm{t}_{\text {tabel }}=2,042$.

Berdasarkan hasil tersebut, maka dinyatakan bahwa $\mathrm{t}_{\text {hitung }}$ jatuh pada daerah penolakan $\mathrm{H}_{\mathrm{o}}$, sehingga dapat ditarik kesimpulan bahwa hipotesis nol $\left(\mathrm{H}_{\mathrm{o}}\right)$ yang menyatakan tidak terdapat pengaruh yang positif dan signifikan antara motivasi terhadap kinerja pegawai "ditolak" dan hipotesis alternatif $\left(\mathrm{H}_{\mathrm{a}}\right)$ yang menyatakan terdapat pengaruh yang positif dan signifikan antara motivasi terhadap kinerja pegawai "diterima". Jadi kesimpulannya $\mathrm{t}_{\text {hitung }}$ jatuh pada daerah $\mathrm{H}_{\mathrm{a}}$ yaitu hipotesis diterima dimana koefisien korelasi antara motivasi terhadap kinerja pegawai sebesar 0,685 adalah positif kuat dan signifikan, artinya koefisien tersebut dapat diberlakukan untuk seluruh populasi.

Uji Hipotesis Pengaruh Kepemimpinan $\left(\mathrm{X}_{1}\right)$ dan Motivasi $\left(\mathrm{X}_{2}\right)$ secara bersama-sama terhadap Kinerja Pegawai (Y)

Hipotesis nol $\left(\mathrm{H}_{\mathrm{o}}\right)$ : Tidak terdapat pengaruh yang positif dan signifikan variabel kepemimpinan $\left(\mathrm{X}_{1}\right)$ dan motivasi $\left(\mathrm{X}_{2}\right)$ secara bersama-sama terhadap kinerja pegawai $(\mathrm{Y})$.

Hipotesis alternatif $\left(\mathrm{H}_{\mathrm{a}}\right)$ : Terdapat pengaruh yang positif dan signifikan variabel kepemimpinan $\left(\mathrm{X}_{1}\right)$ dan motivasi $\left(\mathrm{X}_{2}\right)$ secara bersama-sama terhadap kinerja pegawai $(\mathrm{Y})$.

Adapun sebelum melakukan uji hispotesis korelasi ganda antara kepemimpinan $\left(\mathrm{X}_{1}\right)$ dan motivasi $\left(\mathrm{X}_{2}\right)$ secara bersama-sama terhadap kinerja pegawai $(\mathrm{Y})$, maka terlebih dahulu dihitung korelasi antara kepemimpinan $\left(\mathrm{X}_{1}\right)$ terhadap motivasi $\left(\mathrm{X}_{2}\right)$, dengan rumus sebagai berikut:

$$
\begin{aligned}
\operatorname{rx}_{1} \mathrm{x}_{2} & =\frac{\sum x_{1} x_{2}}{\sqrt{\left(\sum x_{1}^{2}\right)\left(\sum x_{2}^{2}\right)}} \\
& =\frac{4,836}{\sqrt{(6,516)(5,182)}}
\end{aligned}
$$

$$
\begin{aligned}
& =\frac{4,836}{\sqrt{33,761}} \\
& =\frac{4,836}{5,810} \\
& =\quad 0,832
\end{aligned}
$$

Selanjutnya untuk menguji korelasi ganda antara kepemimpinan $\left(\mathrm{X}_{1}\right)$ dan motivasi (X2) secara bersama-sama terhadap kinerja pegawai $(\mathrm{Y})$ pada Direktorat Pengembangan Ekonomi Lokal Kementerian Desa Pembangunan Daerah Tertinggal dan Transmigrasi dapat dihitung dengan rumus sebagai berikut:

$$
\begin{aligned}
& R x_{1} x_{2} y=\sqrt{\frac{r_{x_{1} y}{ }^{2}+r_{x_{2} y}{ }^{2}-2 r_{x_{1} y} \cdot r_{x_{2} y} \cdot r_{x_{1} x_{2}}}{1-r_{x_{1} x_{2}}{ }^{2}}} \\
& R_{X_{1} X_{2} y}=\sqrt{\frac{(0,723)^{2}+(0,685)^{2}-2 \cdot(0,723) \cdot(0,685) \cdot(0,832)}{1-(0,832)^{2}}} \\
& R_{X_{1} X_{2} y}=\sqrt{\frac{(0,522)+(0,470)-0,824}{1-0,693}} \\
& R_{X_{1} X_{2} y}=\sqrt{\frac{0,992-0,824}{0,307}} \\
& R_{X_{1} X_{2} y}=\sqrt{\frac{0,168}{0,307}} \\
& R_{X_{1} X_{2} y}=\sqrt{0,545} \\
& R_{X_{1} X_{2} y}=0,738
\end{aligned}
$$

Berdasarkan hasil perhitungan tersebut, maka koefisien korelasi ganda yang ditemukan adalah $\operatorname{Rx}_{1} x_{2} y=0,738$. Setelah nilai ini dikonsultasikan tabel pedoman interpretasi sebelumnya, maka diketahui bahwa koefisien korelasi ganda tersebut termasuk ke dalam kategori yang kuat. Hal ini menunjukkan bahwa kepemimpinan dan motivasi secara bersama-sama mempunyai pengaruh positif kuat terhadap kinerja pegawai pada Direktorat Pengembangan Ekonomi Lokal Kementerian Desa Pembangunan Daerah Tertinggal dan Transmigrasi. Pengaruh tersebut berlaku untuk seluruh populasi.

Untuk memprediksi besarnya pengaruh antara kepemimpinan dan motivasi secara bersamasama terhadap kinerja pegawai pada Direktorat Pengembangan Ekonomi Lokal Kementerian Desa Pembangunan Daerah Tertinggal dan Trans- 
migrasi dilakukan dengan menghitung koefisien determinasi yaitu dengan rumus mengkuadratkan nilai koefisien korelasi $\left(\mathrm{r}^{2}\right)$ berikut:

$$
\begin{aligned}
\mathrm{Kd} & =\mathrm{r}^{2} \times 100 \% \\
& =(0,738)^{2} \times 100 \% \\
& =0,545 \times 100 \% \\
& =54,5 \%
\end{aligned}
$$

Hal ini berarti kepemimpinan dan motivasi sebesar $54,5 \%$ secara bersama-sama mempengaruhi kinerja pegawai kemudian sisanya 45,5\% dipengaruhi oleh faktor lain.

Selanjutnya untuk menguji signifikansi korelasi ganda antara kepemimpinan dan motivasi secara bersama-sama terhadap kinerja pegawai dalam kemungkinannya untuk diberlakukan dalam seluruh populasi, penulis melakukan pengujian dengan menentukan nilai $\mathrm{F}_{\text {hitung }}$ yang dikonsultasikan dengan nilai $\mathrm{F}_{\text {tabel }}$ dengan sebagai berikut:

$$
\begin{aligned}
& \mathrm{F}_{\text {hit }}=\frac{\mathrm{R}^{2} / \mathrm{k}}{\left(1-\mathrm{R}^{2}\right) /(\mathrm{n}-\mathrm{k}-1)} \\
& \mathrm{F}=\frac{(0,738)^{2} / 2}{\left(1-0,738^{2}\right) /(32-2-1)} \\
& \mathrm{F}=\frac{0,273}{0,455 / 29} \\
& \mathrm{~F}=\frac{0,273}{0,016} \\
& \mathrm{~F}=17,376
\end{aligned}
$$

Jadi, didapat nilai $\mathrm{F}_{\text {hitung }}$ sebesar 17,376 nilai ini selanjutnya dikonsultasikan dengan $\mathrm{F}_{\text {tabel }}$ untuk $\mathrm{dk}$ pembilang $=2 \mathrm{dan} \mathrm{dk}$ penyebut $=(32-$ $2-1)=29$ diperoleh nilai $\mathrm{F}_{\text {tabel }}$ pada taraf kesalahan yang ditetapkan adalah $5 \%=3,33$. Dalam hal ini berlaku ketentuan bila $\mathrm{F}_{\text {hitung }}$ lebih besar dari Ftabel, maka koefisien korelasi ganda yang diuji adalah signifikan, yaitu dapat berlaku untuk seluruh populasi. Dari perhitungan di atas ternyata $\mathrm{F}_{\text {hitung }}>\mathrm{F}_{\text {tabel }}(17,376>3,33)$, maka dapat dinyatakan bahwa korelasi ganda tersebut kuat, positif dan signifikan serta dapat diberlakukan di mana sampel diambil. Dan hipotesis yang berbunyi: Terdapat pengaruh yang positif kuat dan signifikan antara kepemimpinan dan motivasi secara bersama-sama terhadap kinerja pegawai pada Direktorat Pengembangan Ekonomi Lokal
Kementerian Desa Pembangunan Daerah Tertinggal dan Transmigrasi diterima atau terbukti, artinya jika kepemimpinan baik dan motivasi pegawai tinggi, maka kinerja pegawai juga akan meningkat.

\section{Analisis Regresi Berganda}

Analisis regresi berganda digunakan untuk memprediksi seberapa besar perubahan variabel independen (kepemimpinan dan motivasi) terhadap variabel dependen (kinerja pegawai) pada Direktorat Pengembangan Ekonomi Lokal Kementerian Desa Pembangunan Daerah Tertinggal dan Transmigrasi. Di mana analisis regresi berganda ini dinyatakan persamaan:

$$
\mathrm{Y}=\mathrm{a}+\mathrm{b}_{1} \mathrm{X}_{1}+\mathrm{b}_{2} \mathrm{X}_{2}
$$

Dengan rumus sebagai berikut (Sugiyono, 2009):

$$
\begin{aligned}
& b_{1}=\frac{\left(\sum x_{1} y\right)\left(\sum x_{2}^{2}\right)-\left(\sum x_{1} x_{2}\right)\left(\sum x_{2} y\right)}{\left(\sum x_{1}^{2}\right)\left(\sum x_{2}^{2}\right)-\left(\sum x_{1} x_{2}\right)^{2}} \\
& b_{2}=\frac{\left(\sum x_{2} y\right)\left(\sum x_{1}^{2}\right)-\left(\sum x_{1} x_{2}\right)\left(\sum x_{1} y\right)}{\left(\sum x_{1}^{2}\right)\left(\sum x_{2}^{2}\right)-\left(\sum x_{1} x_{2}\right)^{2}} \\
& a=\frac{\sum Y-b_{1}\left(\sum X_{1}\right)-b_{2}\left(\sum X_{2}\right)}{n}
\end{aligned}
$$

Dari tabel penolong untuk menghitung persamaan regresi ganda dua prediktor diperoleh:

$$
\begin{array}{lll}
\Sigma X_{1}=129,067 & \Sigma X_{1}^{2}=527,084 & \Sigma X_{1} \cdot Y=522,916 \\
\Sigma X_{2}=127,867 & \Sigma X_{2}^{2}=516,116 & \sum X_{2} \cdot Y=517,440 \\
\Sigma Y=128,600 & \sum Y_{2}=522,067 & \sum X_{1} \cdot X_{2}=520,564
\end{array}
$$

Di mana:

$$
\begin{array}{rlr}
\Sigma x_{1}{ }^{2} & = & \Sigma \mathrm{X}_{1}{ }^{2}-\left(\Sigma \mathrm{X}_{1}\right)^{2} / \mathrm{n} \\
& = & 527,084-\frac{(129,067)^{2}}{32} \\
& & 527,084-\frac{16658,204}{32} \\
& = & \\
& = & 527,084-520,569 \\
& = & 6,516 \\
\Sigma x_{2}{ }^{2} & = & \Sigma \mathrm{X}_{2}{ }^{2}-\left(\Sigma \mathrm{X}_{2}\right)^{2} / \mathrm{n} \\
& & 516,116-\frac{(127,867)^{2}}{32} \\
& = &
\end{array}
$$




$$
\begin{aligned}
& =\quad 516,116-\frac{16349,884}{32} \\
& =\quad 516,116-510,934 \\
& =\quad 5,182 \\
& \Sigma y^{2}=\Sigma \mathrm{Y}^{2}-(\Sigma \mathrm{Y})^{2} / \mathrm{n} \\
& =\quad 522,067-\frac{(128,600)^{2}}{32} \\
& =\quad 522,067-\frac{16537,960}{32} \\
& =\quad 522,067-516,811 \\
& =5,255 \\
& \Sigma x_{1} \cdot x_{2}=\quad \Sigma \mathrm{X}_{1} \cdot \mathrm{X}_{2}-\frac{\left(\Sigma \mathrm{X}_{1}\right) \cdot\left(\Sigma \mathrm{X}_{2}\right)}{\mathrm{n}} \\
& =\quad 520,564-\frac{(129,067)(127,867)}{32} \\
& =\quad 520,564-\frac{16503,324}{32} \\
& =\quad 520,564-515,729 \\
& =\quad 4,836 \\
& \Sigma x_{1} y=\quad \Sigma \mathrm{X}_{1} \cdot \mathrm{Y}-\frac{\left(\Sigma \mathrm{X}_{1}\right) \cdot(\Sigma \mathrm{Y})}{\mathrm{n}} \\
& =\quad 522,916-\frac{(129,067)(128,600)}{32} \\
& =\quad 522,916-\frac{16597,960}{32} \\
& =\quad 522,916-518,687 \\
& =\quad 4,229 \\
& \Sigma x_{2} \cdot y=\quad \Sigma \mathrm{X}_{2} \mathrm{Y}=\frac{\left(\Sigma \mathrm{X}_{2}\right) \cdot(\Sigma \mathrm{Y})}{\mathrm{n}} \\
& =\quad 517,440-\frac{(127,867)(128,600)}{32} \\
& =\quad 517,440-\frac{16443,653}{32} \\
& =\quad 517,440-513,864 \\
& =\quad 3,576
\end{aligned}
$$

Selanjutnya untuk menghitung harga-harga atau nilai-nilai konstan (a), b1, dan b2 adapun perhitungannya dengan rumus sebagai berikut:

$$
\begin{aligned}
& b_{1}=\frac{\left(\sum x_{1} y\right)\left(\sum x_{2}^{2}\right)-\left(\sum x_{1} x_{2}\right)\left(\sum x_{2} y\right)}{\left(\sum x_{1}^{2}\right)\left(\sum x_{2}{ }^{2}\right)-\left(\sum x_{1} x_{2}\right)^{2}} \\
& =\frac{(4,229) \cdot(5,182)-(4,836) \cdot(3,576)}{(6,516) \cdot(5,182)-(4,836)^{2}}
\end{aligned}
$$

$$
\begin{aligned}
& =\frac{21,913-17,291}{33,761-23,383} \\
& =\frac{4,622}{10,379} \\
& =0,445 \\
& b_{2}=\frac{\left(\sum x_{2} y\right)\left(\sum x_{1}^{2}\right)-\left(\sum x_{1} x_{2}\right)\left(\sum x_{1} y\right)}{\left(\sum x_{1}^{2}\right)\left(\sum x_{2}^{2}\right)-\left(\sum x_{1} x_{2}\right)^{2}} \\
& \frac{(3,576) \cdot(6,516)-(4,836) \cdot(4,229)}{(6,516) \cdot(5,182)-(4,836)^{2}} \\
& =\quad \frac{23,299-20,449}{33,761-23,383} \\
& =\frac{2,850}{10,379} \\
& =0,275 \\
& =\frac{\sum Y-b_{1}\left(\sum X_{1}\right)-b_{2}\left(\sum X_{2}\right)}{n} \\
& \frac{128,600-0,445(129,067)-0,275(127,867)}{32}
\end{aligned}
$$

Berdasarkan hasil perhitungan tersebut diperoleh:

$$
\begin{aligned}
& \mathrm{a}=1,126 \\
& \mathrm{~b}_{1}=0,445 \\
& \mathrm{~b}_{2}=0,275
\end{aligned}
$$

Dari nilai konstanta a dan koefisien regresi b1 dan b2 di atas kemudian dapat dibuat persamaan regresinya, yaitu:

$$
\begin{array}{ll}
\hat{\mathrm{Y}} & =\mathrm{a}+\mathrm{b}_{1} \mathrm{X}_{1}+\mathrm{b}_{2} \mathrm{X}_{2} \\
\hat{\mathrm{Y}} & =1,126+0,445 \mathrm{X}_{1}+0,275 \mathrm{X}_{2}
\end{array}
$$

Untuk persamaan regresi kepemimpinan dan motivasi secara bersama-sama terhadap kinerja pegawai adalah: $\hat{\mathrm{Y}}=1,126+0,445 \mathrm{X}_{1}+0,275 \mathrm{X}_{2}$. Hal ini berarti tinggi rendahnya kinerja pegawai karena kepemimpinan dan motivasi dapat diprediksikan melalui persamaan regresi tersebut.

Berdasarkan data skor kepemimpinan dan motivasi yang tertinggi adalah 75 ( 5 x 15). 5 adalah nilai tertinggi tiap jawaban dan 15 adalah jumlah item pertanyaan. Oleh karena itu, kinerja pegawai adalah:

$$
\begin{aligned}
\hat{Y} & =1,126+0,445+0,275 \cdot 75 \\
& =1,126+53,988 \\
& =55,113
\end{aligned}
$$

Ternyata jika kepemimpinan dan motivasi ditingkatkan sampai 75 satuan, maka kinerja pegawai meningkat dari 1,126 satuan menjadi 55,113 satuan. Hal ini berarti semakin baik ke- 
pemimpinan dan semakin tinggi motivasi pegawai, maka semakin meningkat pula kinerja pegawai pada Direktorat Pengembangan Ekonomi Lokal Kementerian Desa Pembangunan Daerah Tertinggal dan Transmigrasi.

\section{Pembahasan}

Berdasarkan hipotesis yang diajukan pengaruh kepemimpinan dan motivasi terhadap kinerja pegawai pada Direktorat Pengembangan Ekonomi Lokal Kementerian Desa Pembangunan Daerah Tertinggal dan Transmigrasi, maka perlu dibahas eksistensi masing-masing variabel.

Berdasarkan hasil penelitian variabel kepemimpinan $\left(\mathrm{X}_{1}\right)$ memiliki pengaruh yang positif kuat dan signifikan dengan nilai koefisien korelasi sebesar 0,723 , sedangkan nilai koefisien determinasi $\left(\mathrm{r}^{2}\right)$ sebesar 0,522 , artinya variabel kepemimpinan memberikan kontribusi sebesar $52,2 \%$ dalam menjelaskan variabel kinerja pegawai.

Adapun untuk variabel motivasi $\left(\mathrm{X}_{2}\right)$ mempunyai pengaruh yang positif kuat dan signifikan terhadap kinerja pegawai, yakni dengan nilai koefisien korelasinya sebesar 0,685 , sedangkan nilai koefisien determinasi $\left(\mathrm{r}^{2}\right)$ sebesar 0,470 , artinya variabel motivasi memberikan kontribusi sebesar 47,0\% dalam menjelaskan kinerja pegawai.

Dari hasil analisis secara simultan, menunjukkan bahwa kepemimpinan dan motivasi berpengaruh positif kuat dan signifikan terhadap kinerja pegawai. Hal ini tingkat kepemimpinan secara langsung mempengaruhi kinerja pegawai, telah terbukti secara signifikan dari hasil penelitian secara parsial maupun secara simultan diketahui bahwa kinerja pegawai pada Direktorat Pengembangan Ekonomi Lokal Kementerian Desa Pembangunan Daerah Tertinggal dan Transmigrasi dapat ditentukan oleh faktor-faktor kepemimpinan dan motivasi yakni terlihat kontribusi pengaruh yang dihasilkan $\left(\mathrm{r}^{2}\right)$ sebesar $54,5 \%$ dan selebihnya $45,5 \%$ ditentukan oleh faktor lain di luar model penelitian ini.

Untuk pengaruh variabel $\mathrm{X}_{1}$ (kepemimpinan) terhadap Y (kinerja pegawai) perlu dianalisis penulis karena kepemimpinan adalah kemampuan pemimpin dalam mempengaruhi orang lain, dalam melakukan kerja sama untuk mencapai tu- juan yang telah ditentukan. Jadi kepemimpinan merupakan aspek yang paling nyata dari kegiatan manajemen, yang berindikasikan fokus, pengaruh, tingkah laku dan tujuan.

Untuk pengaruh variabel $\mathrm{X}_{2}$ (motivasi) terhadap Y (kinerja pegawai) perlu dianalisis penulis karena motivasi adalah interaksi seseorang dengan situasi tertentu yang dihadapinya orang tersebut dan di dalam dirinya terdapat "kebutuhan" atau "keinginan" terhadap obyek di luar diri orang tersebut, kemudian bagaimana dia menghubungkan antara kebutuhan dengan "situasi di luar" obyek tersebut dalam rangka memenuhi kebutuhan yang dimaksud melalui berbuat berarti, imbalan, bersikap adil, umpan balik dan bergaul dengan rekan kerja.

Untuk pengaruh variabel $\mathrm{X}_{1}$ (kepemimpinan) dan $\mathrm{X}_{2}$ (motivasi) secara bersama-sama terhadap variabel Y (kinerja pegawai) perlu dianalisis penulis karena kinerja pegawai adalah hasil kerja yang dapat dicapai oleh seseorang atau sekelompok orang dalam suatu organisasi melalui kualitas kerja yang dihasilkan, kuantitas, baik secara kuantitatif maupun kualitatif, sesuai dengan kewenangan dan tugas tanggung jawab masing-masing, sikap pegawai dan konsistensi pegawai serta tidak melanggar hukum dan sesuai dengan moral dan etika dikarenakan adanya motivasi yang tinggi.

Dengan mengidentifikasi variabel kepemimpinan dan motivasi, maka hal itu akan berpengaruh terhadap kinerja pegawai. Berdasarkan pemikiran di atas menurut penulis hipotesis yang menyatakan bahwa kepemimpinan dan motivasi memiliki pengaruh yang kuat terhadap kinerja pegawai pada Direktorat Pengembangan Ekonomi Lokal Kementerian Desa Pembangunan Daerah Tertinggal dan Transmigrasi dapat diterima.

Besarnya pengaruh kedua variabel bebas tersebut dengan variabel terikat juga menunjukkan kenyataan bagaimana melaksanakan dan meningkatkan kinerja pegawai dengan optimal, kenyataan ini telah terjawab dengan adanya kepemimpinan yang baik dan motivasi yang tinggi. Secara praktis bahwa kedua variabel berjalan secara bersamasama, artinya dalam prosesnya kepemimpinan dan motivasi dapat menjadi variabel atau faktor 
yang menentukan apakah kinerja pegawai tinggi atau rendah.

Apabila kepemimpinan baik dan motivasi tinggi, maka dengan sendirinya kinerja pegawai akan meningkat. Pada pembahasan ini penulis berkesimpulan bahwa dari kedua variabel bebas di atas menunjukkan adanya pengaruh yang sangat berarti, artinya tanpa kepemimpinan yang baik dan motivasi yang tinggi, maka kinerja pegawai pada Direktorat Pengembangan Ekonomi Lokal Kementerian Desa Pembangunan Daerah Tertinggal dan Transmigrasi tidak dapat ditingkatkan secara maksimal.

\section{SIMPULAN}

Berdasarkan hasil penelitian yang dilakukan penulis bahwa faktor kepemimpinan di Direktorat Pengembangan Ekonomi Lokal Kementerian Desa Pembangunan Daerah Tertinggal dan Transmigrasi sangat mempengaruhi kinerja pegawai. Artinya jika kepemimpinan dilaksanakan dengan baik maka kinerja pegawai akan meningkat.

Berdasarkan hasil penelitian yang dilakukan penulis bahwa faktor motivasi di Direktorat Pengembangan Ekonomi Lokal Kementerian Desa Pembangunan Daerah Tertinggal dan Transmigrasi sangat mempengaruhi kinerja pegawai. Artinya jika motivasi pegawai tinggi maka kinerja pegawai akan meningkat.

Berdasarkan hasil penelitian yang dilakukan penulis bahwa faktor kepemimpinan dan motivasi pegawai di Direktorat Pengembangan Ekonomi Lokal Kementerian Desa Pembangunan Daerah Tertinggal dan Transmigrasi secara bersamasama sangat mempengaruhi kinerja pegawai. Artinya jika kepemimpinan dilaksanakan dengan baik dan motivasi pegawai tinggi maka kinerja pegawai akan meningkat.

\section{PENGHARGAAN}

Untuk pembiayaan penelitian ini dibiayai sendiri. Rasa terima kasih kami ucapkan kepada Direktorat Pengembangan Ekonomi Lokal Kementerian Desa, Pembangunan Daerah Tertinggal, dan Transmigrasi yang telah men dukung keberhasilan penelitian ini.

\section{DAFTAR PUSTAKA}

Bangun, W. (2008). Intisari Manajemen. Bandung: Refika Aditama.

Hasibuan, M. S.P. (2014). Manajemen Sumber Daya Manusia. Jakarta: Bumi Aksara

Kartono, K. (2005). Kepemimpinan: Apakah Kepemimpinan Abnormal Itu? Jakarta: Raja Grafindo Persada.

Mahsun, M. (2009). Pengukuran Kinerja Sektor Publik. Yogyakarta: BPFE.

Mangkunegara, A.A. A.P. (2004). Manajemen Sumber Daya Manusia Perusahaan. Jakarta: Remaja Rosdakarya.

Mar'af. (2000). Kepemimpinan Positif dalam Manajemen. Jakarta: Rineka Cipta.

Marihot, M. (2001). Manajemen Sumber Daya Manusia. Yogyakarta: BPFE.

Maslow, A.H. (2000). Motivation and Personality. New York: Harper and Now.

Munandar, A S. (2001). Psikologi Industri dan Organisasi. Jakarta: VI Press.

Moeheriono. (2009). Pengukuran Kinerja Berbasis Kompetensi. Ciawi-Bogor: Ghalia Indonesia.

Notoatmodjo, S. (2009). Pengembangan Sumber Daya Manusia. Jakarta: Rineka Cipta.

Prawirosentono, S. (2000). Kebijakan Kinerja Pegawai. Yogyakarta: BPFE.

Riduwan. (2004). Metode \& Teknik Menyusun Tesis. Bandung: Alfabeta.

Rivai, V. (2006). Kiat Kepemimpinan Dalam Abad Ke 21. Jakarta: Murai Kencana.

Robbins, S. P. (2001). Perilaku Organisasi, Alih Bahasa Tim Indeks. Jakarta: Indeks Kelompok Gramedia.

Ruky, A. S. (2002). Sistem Manajemen Kinerja. Jakarta: Gramedia Pustaka Utama.

Sedarmayanti.(2009). Tata Kerjadan Produktivitas Kerja. Bandung: Mandar Maju.

Siagian, S. P. (2004). Teori Motivasi dan Aplikasinya. Jakarta : Rineka Cipta.

Simanjuntak, P. J. (2005). Manajemen dan Evaluasi Kinerja. Jakarta: LPFE UI.

Sudriamunawar, H. (2006). Kepemimpinan, Peran Serta dan Produktivitas. Bandung: Mandar Maju.

Sugiyono. (2014). Metode Penelitian Administrasi. 
Bandung: Alfabeta.

Sutrisno, E. (2009). Manajemen Sumber Daya

Manusia. Jakarta: Kencana Prenada Media

Group.

Suwatno, \& Priansa, D. J. (2011). Manajemen

SDM dalam Organisasi Publik dan Bisnis.

Bandung: Alfabeta.

Wahjosumidjo. (2002). Kepemimpinan dan Motivasi. Jakarta: Ghalia Indonesia.

Wibowo. (2009). Manajemen Kinerja. Jakarta :

Raja Grafindo Persada. 